\title{
Mechanically deboned meat
}

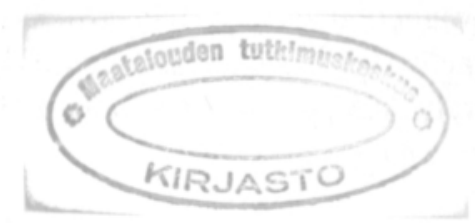

\section{RIIHONEN,* J. LAINE* and P. LINKO**}

* Finnish Meat Research Centre, Box 56, SF-13101 Hämeenlinna, Finland

** Laboratory of Biotechnology and Food Engineering, Department of Chemical Engineering, Helsinki University of Technology, SF-02150 Espoo, Finland

\begin{abstract}
Mechanically deboned meat (MDM) and mechanically deboned tissue (MDT) are used in the meat industry to an ever-increasing degree. The quality of mechanically deboned meat, its high protein content, good technological characteristics and comparatively low cost make the product a profitable and useful raw material. Mechanically deboned meat is a wholesome, nutritious, highly palatable product with a bright future as food. Its properties permit its incorporation in the production of heat-processed meat products composed of comminuted raw materials. Regulations are given in the legislation of several countries concerning the chemical composition, use and storage of such meat.
\end{abstract}

Index words: Mechanically deboned meat, composition, microbiological quality, colour, packaging

\section{MECHANICAL DEBONING}

The oldest mechanical meat separator is said to have been a drum-type separator, adapted by the Japanese fish industry in early 1940's. The machine consisted of a belt and a perforated beltwheel. When the fish bones fell inside the rotating belt, they were crushed against the drum and the meat passed through the perforations into the drum. The second type of separator to be developed was a rotating auger and the third was a pressure roller (1).
Today's methods are grouped according to their operating principles: 1) Ground bones are pressed against a filter, separating the bone from the meat (e.g. Paoli, Beehive, Lynggaard). The newest development of such equipment is a device into which a spiral conveyor brings the crushed bone-and-meat and where a knife-pack cuts the meat from the bones (Poss). 2) The bones are pressed against a filter and only the meat passes through (e.g. Baaijens, Protecon, Inject Star, Amersfoort, 
Laska, Hydrau). 3) Finely ground bones are mixed with salt water and centrifuged (KSHerta-equipment).

Various chemical, biochemical and physical separation methods have been investigated in conjunction with mechanical deboning but in practice the mechanical deboning methods generally used almost all belong to one of the above gategories (2).

\section{FACTORS GOVERNING MECHANICAL DEBONING AND THE RECOVERED MEAT}

The machines handle either chopped bones or bones precleaned with a knife to varying degrees. The quality and quantity of deboned meat is governed by age, breed and animal species, origin of bone, quality and method of meat separation, ratio of meat to bone and also of skin on poultry bones.

Mechanically deboned meat generally differs from other meat primarily in the content of substances originating from bones and bone marrow. These are mainly calcium,phosphorus, fluorine, iron and some lipid compouds. According to most investigations (1), these substances are a benefit rather than a disadvantage to the meat industry and to the customers. However, their usage is restricted or forbidden in products intended for special use. The origin of bone has a noticeable effect on the quality of deboned meat. According to Goldstrand (3) the chemical composition of meat separated from the neck bones of a pig is $14.2-15.1 \%$ protein, $24.7-29.9 \%$ fat and 53.7-60.3\% moisture. Field et al. (4) reported that the highest protein content is encountered in meat separated from the sow loin bones $(14.01 \%)$, veal frame bones $(17.57 \%)$, veal backbones (15.98\%) and beef neck bones $(17.18 \%)$. These authors separated meat by a Beehive-machine, in which the perforation size of the cylinder was $0.46 \mathrm{~mm}$. The highest fat contents were in meat separated from blade bones $(42.37 \%)$ and thigh bones $(41.89 \%)$. As would be anticipated, meat separated from bones having a higher meat content also has a higher protein content, whereas meat separated from bones having less meat content has a higher fat content due to bone substance and bone marrow. According to Goldstrand (3) meat mechanically separated from the bones of a low-fat bull had a high protein content $(16-17 \%)$ and little fat $(9.9-24.4 \%)$. He also reported that meat separated from ham bones contains $10.0 \%$ protein, $42.3 \%$ fat and $44.6 \%$ moisture. These results are rather similar to those published by Field et al. (4).

Mechanically deboned meat presents two main problems for its utilization (5). The first is the physical quality of the product produced. Because the meat has lost its muscular structure it may have a high potential for developing rancidity. Its largely amorphous nature, possibly strong color, and relatively poor keeping qualities limit its potential usage. The second drawback is connected with nutritional quality: the fat, bone and connective tissue content of MDM could introduce important health considerations if used in large quantities, although acceptable if it is used as an ingredient in compound foods. Technology should aim towards a better quality product both physically and nutritionally, although one will probably follow with the improvement of the other (6).

With continually increasing demands on the world's food supply, new techniques, improvements of old methods, improved recovery and utilisation of waste and the introduction of novel foods are all becoming increasingly important.

\section{Mineral content}

The most important minerals in deboned meat are calcium and iron. The average calcium content of bones of varying ages, derived from different animal species and anatomical sites, is about $37 \%$ of the ash content of the bones (7). The ash and calcium contents increase with age and calcification. The calcium content of mechanically deboned meat de- 
pends not only on the species of animal and origin of bones, but also conclusively on the type of machine used for cleaning the bones. When the deboning is based on scraping, the calcium content is generally greater than that achieved by other machine types.

When comparing calcium and ash contents of meat derived from different anatomical sites and species separated in the same machine, the sow loin bones and the veal back bones gave the lowest values, $0.41 \%$ and $0.54 \%$ calcium and $1.77 \%$ and $2.21 \%$ ash (8). Lean that is free from bone contains approximately $12 \mathrm{mg}$ of calcium per $100 \mathrm{~g}$, and its ash content is about $1.2 \%$, whereas fat contains $3 \mathrm{mg}$ of calcium per $100 \mathrm{~g}$ and $0.2 \%$ ash $(9,10)$. Many countries have legislative norms for calcium content.

Djujic et al. (11) published one of the most extensive reports on the mineral content of mechanically and hand deboned meat. The sample of mechanically separated meat was taken immediately after the mass had been well mixed, from several places in the container.

The iron content of mechanically deboned meat has been studied extensively. The bone itself contains very little iron (about $0.01 \%$ ). Thus, the iron content of mechanically deboned meat indicates how much bone marrow has got into the meat. The iron content can also be used as a basis for comparison when examining different types of machines. According to Field at al. (12) the neck bone marrow of a bull contains $23.0 \mathrm{mg}$ iron in $100 \mathrm{~g}$, where as hip bone marrow contains $13.1 \mathrm{mg}$ iron in $100 \mathrm{~g}$. The iron content of mechanically deboned meat can vary greatly according to the origin of the bone and the type of machine used in separation.

\section{Protein content}

\section{Amino acid composition}

The amino acid composition of mechanically deboned meat has been studied e.g. by Prost (13), who compared the composition of meat from pork shoulder and blade bones with sirloin.

A Seffelaar-Looyen bone separator was used. The pigs used weighed approx. 100-110 $\mathrm{kg}$. The fat content, protein content and PER (protein efficiency ratio) in the meat separated from humerus bones were $46.11 \%, 8.74 \%$ and 2.50 respectively. The corresponding figures for meat separated from shoulder-blade bones (scapula) were: $27.63 \%, 12.35 \%$ and 2.50 , and for meat separated from longissimus dorsi: $5.57 \%, 21.62 \%$ and 2.80 . From these figures, as well as from those quoted earlier, it can be concluded that the protein content increases as the fat content decreases. PER is almost the same in all cases. Of the most essential amino acids the quantities of methionine and tyrosine are higher in meat separated from longissimus dorsi, whereas the opposite applies to leucine. The amino acid compositions of meat separated in a Beehive machine (cylinder perforation size $0.46 \mathrm{~mm}$ ) from the right-side flat bones of a good quality beef carcass (MDM) and from corresponding flat bones from the left side (MST) are presented in Table 1 (14). The bones of the left side were

Table 1. Amino acid composition of mechanically deboned meat (MDM) and mechanically separated tissue (MST) $^{\mathrm{a}}(14)$

\begin{tabular}{lrr}
\hline Amino acid & MDM & MST \\
\hline Threonine & 4.2 & 3.7 \\
Valine & 6.8 & 6.4 \\
Methionine & 1.7 & 1.6 \\
Isoleucine & $4.0^{\mathrm{b}}$ & 2.7 \\
Leucine & 7.2 & 6.5 \\
Phenylalanine & 4.0 & 4.0 \\
Lysine & 7.4 & 7.2 \\
Histidine & 3.1 & 3.0 \\
Arginine & 6.7 & 6.8 \\
Tyrosine & 2.9 & 2.5 \\
Aspartic acid & 8.5 & 8.2 \\
Serine & 3.8 & 3.8 \\
Glutamic acid & 12.5 & 12.4 \\
Proline & 6.2 & 8.3 \\
Glycine & 7.2 & 8.4 \\
Alanine & 6.5 & 7.1 \\
\hline
\end{tabular}

a All values are expressed as the percentage in the crude protein $\mathrm{N} \times 6.25$ ) and are the average of triplicate analyses on each of four different lots of MDM and MST. Means on the same line bearing different letters differ significantly $(\mathrm{P}<0.05)$. 
carefully hand cleaned before mechanical cleaning. The results show that the isoleucine content of MDM is noticeably higher than that of MST. The reason for this is the higher content of collagen in MST, because collagen contains very little isoleucine. The collagen content of MST was $6.72 \%$ and the corresponding content of MDM was $2.63 \%$.

The amino acid composition of mechanically recovered meat is of great importance in estimating its nutritional value. Essary et al. (15) in their studies on mechanically recovered turkey meat reported that the amino acid content was comparable with that of hand boned meat. Chang et al. (16) found that sulphur amino acids and isoleucine were limiting factors in mechanically recovered red meat. They were, therefore good indicators of protein quality, the highest quality protein coming from bones with large amounts of muscle adhering to them.

\section{Fat content}

The fat content of mechanically deboned meat is slightly higher than that of meat on average, due to the additional fat from bone marrow. The composition of fat in marrow bones differs from that of subcutaneous and intramuscular fat primarily because it contains more polyunsaturated fatty acids, phospholipids and cholesterol. Nevertheless the composition of fat in mechanically deboned meat is very similar to that of the fat of hand boned meat. The actual bone content in bonemeat is about $0.5-3.0 \%$ and fat content in bone is $0.06-0.10 \%$. The fat content of bone marrow increases and changes in composition as the animal ages (17).

\section{Lipid oxidation catalysts}

\section{Catalytical effect of metmyoglobin}

Substances catalyzing lipid oxidation have been studied for a long time. It has been shown that meat from which bone has been mechanically removed is an excellent growth medium for microorganisms and, at the same time, that the quality of lipids deteriorates with storage. The reasons for this are contact of meat with a metal surface during mechanical removal of bone, the temperature increase during bone removal and blend of the meat with oxygen. At the same time, the bone marrow releases heme pigments, increasing the heme protein content (18).

Earlier studies (19) also indicate that chicken and fish triglycerides and phospholipids, which contain high levels of polyunsaturated fatty acids, are definetely associated with lipid oxidation. Similar conclusions were reached by Sato et al. (20) who confirmed that heme iron concentrations up to $10 \mathrm{mg} / \mathrm{g}$ do not necessarily have an effect on lipid oxidation.

According to Liu (21), heme proteins and non-heme protein compounds behave as active catalysts in lipid oxidation reactions. Metmyoglobin speeds lipid oxidation in the $\mathrm{pH}$ range 5.6-7.8, and the catalytical influence increases with increase in $\mathrm{pH}$. Non-heme compounds act catalytically below pH 6.4. When the $\mathrm{pH}$ exceeds 7.8, lipid oxidation is considerably reduced, probably because the enzymatic reducing systems in meat are very active, utilizing the available oxygen and maintaining myoglobin in the reduced form, which is believed to be inactive as a catalyst.

In another connection Liu (22) confirmed that even though myoglobin remains catalytically inactive in raw meat, it does have an effect on cooked meat. In this case the high temperature has inactivated the deoxidizing enzymes and changed heme iron into non-reversible Fe-ions. This non-heme iron acts as a catalyst in cooked and stored meat. In addition to these effects a quantity of heme pigment is lost during heating and storage. Barbut et.al (23) showed that the total iron content is not necessarily a good indicator of the potential for lipid oxidation. The form of iron which is most catalytic has not been firmly established. Both heme and non-heme iron catalyze lipid oxidation in meat. Some investigators have reported that heme proteins are the predominant catalysts, while others examined 
heme and fat oxidation in turkey meat at various storage temperatures and confirmed that the oxidation of lipids and heme proteins accelerates at $+10^{\circ} \mathrm{C}(24,25)$. Clearly the temperature of $+10^{\circ} \mathrm{C}$, used in the cleaning of bones, should not be exceeded. The catalytical effect of metmyoglobin and various metal ions such as $\mathrm{Fe}^{2+}, \mathrm{Cu}^{2+}$ and $\mathrm{Co}^{2+}$ on lipid oxidation in raw and cooked meats of different types was studied by Tichivangana et al. (26). They concluded that the increase in lipid oxidation during cooking of the meat was caused by the release of non-heme iron. Lipid oxidation in meat fat of cooked lamb and beef was noted after five days of storage at $+4^{\circ} \mathrm{C}$. $\mathrm{Fe}$-ions had clearly the highest catalytical impact, with the order: $\mathrm{Fe}^{2+}>\mathrm{Cu}^{2+}>\mathrm{Co}^{2+}>$ MetMb. Of the samples examined, fish was most susceptible to oxidation, and the order for the different meats was: fish $>$ turkey $>$ chicken $>$ pork $>$ beef $>$ lamb. The above order indicates the degree of unsaturation of the triglycerides. The catalytical effect of metmyoglobin on lipid oxidation becomes clear from Table 2.

The effect of anti-oxidants, which prevent lipid oxidation, has been widely studied. Smith (25) investigated lipid oxidation both in hand boned and Beehive-machine boned turkey meat during packing and storage. Teno $\times$ $2^{R}$, containing butylated hydroxyanisole, propylgallate and citric acid, was used as an antioxidant at a concentration of $0.02 \%$. The lipid quality was analysed with the thiobarbituric acid test. The meat was packed in mylarpolyethylene film, stored at $-20^{\circ} \mathrm{C}$, and defrozen at $+4^{\circ} \mathrm{C}$ (Figure 1). The effect of the anti-oxidant preparation is clearly evident in both meat samples. TBA numbers did not differ significantly between the meats from the two deboning methods at the same storage interval.

Moerck and Ball (27) noticed, that polyunsaturated fatty acids in particular were oxidized during the storage of mechanically separated chicken meat. After 15 days of storage the ratio of polyunsaturated fatty acids decreased from $25.5 \%$ to $13 \%$. The level of oxidation was highest after six days of cold storage. Yasosky et al. (28) examined the effect of $\mathrm{pH}$ on lipid oxidation in fresh pork, and also the catalytical effect of metmyoglobin (MetMb). They confirmed that high $\mathrm{pH}$ values ( $\mathrm{pH}$ 6.10) were less favourable to lipid oxidation. They found no correlation between MetMb content and lipid oxidation, and concluded that MetMb has no catalytical effect on lipid oxidation of raw meat at high $\mathrm{pH}$ ranges.

Young et al. (29) published results of the comparison of lipid, purine, nucleid acid and cholesterol contents of mechanically deboned meat and meat in general, and concluded that by giving limits to cholesterol, adenine or guanine contents of the meat, the other nucleic acids could also be controlled. In this

Table 2. Rates of lipid catalyzed by metmyoglobin $(5 \mathrm{mg} / \mathrm{g})$ and metals $(5 \mathrm{mg} / \mathrm{kg})$ in raw and heated water-extracted (WE) muscle systems from several species stored at $4^{\circ} \mathrm{C}$ for 5 days. (26)

\begin{tabular}{|c|c|c|c|c|c|c|c|c|c|c|}
\hline \multirow[t]{2}{*}{ Muscle } & \multicolumn{2}{|c|}{ Control $^{b}$} & \multicolumn{2}{|c|}{ MB } & \multicolumn{2}{|c|}{$\mathrm{Fe}^{+2}$} & \multicolumn{2}{|c|}{$\mathrm{Cu}+2$} & \multicolumn{2}{|c|}{$\mathrm{Co}^{+2}$} \\
\hline & R & $\mathrm{H}$ & R & $\mathrm{H}$ & $\mathrm{R}$ & $\mathrm{H}$ & $\mathrm{R}$ & $\mathrm{H}$ & $\mathbf{R}$ & $\mathrm{H}$ \\
\hline Fish & 0.14 & 0.16 & 0.28 & 2.70 & 2.71 & 4.37 & 2.30 & 3.88 & 1.48 & 3.29 \\
\hline Turkey & 0.13 & 0.15 & 0.27 & 2.18 & 1.89 & 3.84 & 1.61 & 3.45 & 1.04 & 2.79 \\
\hline Chicken & 0.13 & 0.15 & 0.26 & 1.98 & 1.77 & 3.73 & 1.58 & 3.32 & 0.98 & 2.38 \\
\hline Pork & 0.12 & 0.13 & 0.23 & 1.82 & 1.42 & 3.27 & 1.04 & 2.84 & 0.61 & 2.10 \\
\hline Beef & 0.09 & 0.10 & 0.16 & 1.19 & 0.62 & 2.13 & 0.49 & 1.77 & 0.33 & 1.29 \\
\hline Lamb & 0.07 & 0.09 & 0.12 & 0.86 & 0.44 & 1.09 & 0.33 & 1.06 & 0.24 & 0.89 \\
\hline
\end{tabular}

- Mean TBA values per day of four replicates carried out in duplicate.

b Muscle systems without additives.

$R$, raw.

$\mathrm{H}$, heated. 


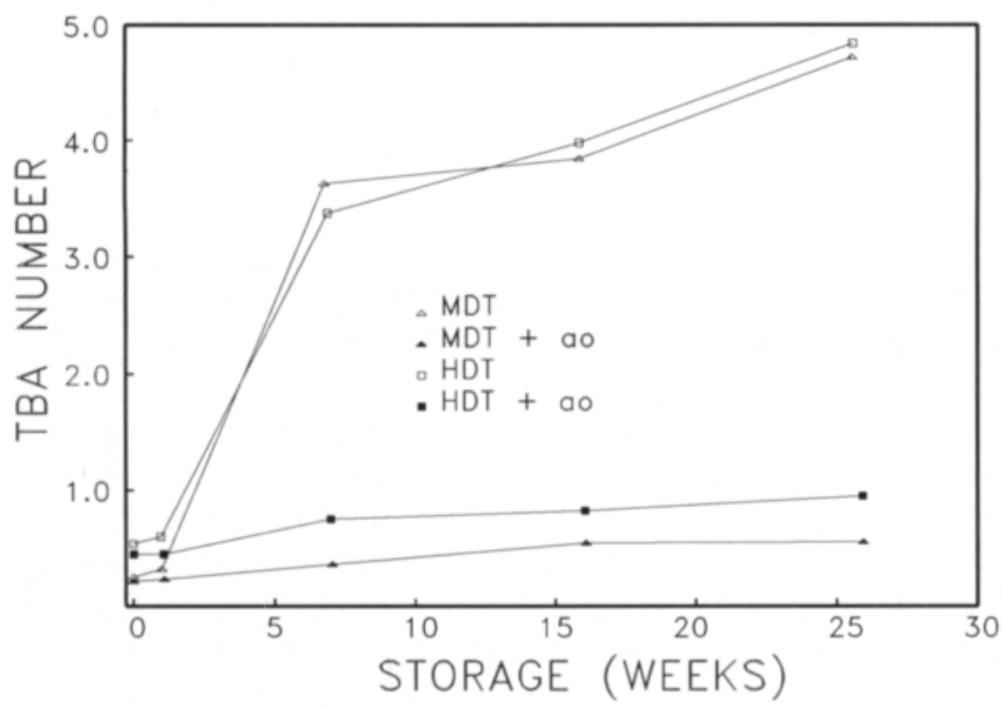

Fig. 1. Influence of frozen storage at $-20^{\circ} \mathrm{C}$ and antioxidant use on mean TBA values of hand deboned turkey and mechanically deboned turkey. TBA measured as mg malonaldehyde/ $\mathrm{kg}$ meat (25). (MDT: mechanically deboned turkey; MDT + ao: mechanically deboned turkey with antioxidant; HDT: hand deboned turkey; HDT + ao: hand deboned turkey with antioxidant) way, bones releasing the least bone marrow into the meat could be chosen (30).

The enzymatic lipid oxidation of mechanically deboned meat is not possible, because in animal tissue there is no lipoxidase.

The presence of backbone marrow can be eliminated by using ribs and other long bones. These bones, however, are easy to clean by hand, leaving very little meat for mechanical cleaning. Thus, meat obtained through mechanical cleaning contains more bone marrow than it would if the bones for cleaning could be sorted out some other way (31). In the case of old and poor quality beef only bones from the vertebra are used. From pork and lamb, ribs and neck bones are used in addition to backbones (4). Mechanically deboned beef contains more bovine hemopoietic marrow, because beef neck bones are larger than those of pork or lamb (32).

\section{Presence of solid bone particles}

Mechanically deboned meat contains small amounts of bone particles, the size and quantity of which depend on the machine used, the perforation size and the condition of the strainers (33). The bones themselves have a bearing on the bone content of the separated meat, because hard bones shatter more easily than soft bones, and small fragments pass through most easily. The bones of older animals contain more calcium, and are therefore harder than those of young animals (34). The bone particle content of the meat depends on the meatiness of the bones used for deboning. There are norms in the legislation of several countries concerning the bone content of mechanically deboned meat, stipulating both the size and the calcium content of the bone particles. Bijker et al. (35) published test results in which they compared for example the sizes of bone particles from different animal species and various anatomical bone sites. They used several different machines based on separation by pressure. According to the results obtained, the proportion of bone matter $(<0.4 \%)$ in such meat is considerably smaller than in meat separated in an augertype machine (2.8-4\%). Schuler (36) studied poultry meat separated in different auger-type machines:

1) Yield Master, diameter of separation aperture $0.50 \mathrm{~mm}$

2) Poss P-DX 1, " " " " $0.45 \mathrm{~mm}$

3) Meat Maker, " " " " " $0.79 \mathrm{~mm}$ 4) Beehive, " " " " $0.60 \mathrm{~mm}$

The size of bone particles in the tested meat was examined using strainers with perforation sizes of $0.35 \mathrm{~mm}$ and $0.50 \mathrm{~mm}$. No noticeable difference was found between the meat deboned using the two different strainers. 
In his paper 'Mechanically Deboned Red Meat' Field (37) reported that the bone content in meat hand boned from pork head and neck bones was $0.05-0.31 \%$. He also stated that a bone particle range of between $12-840$ $\mu \mathrm{m}$ can be considered safe for teeth as well as for digestion.

Tso et al. (38) showed that mechanical deboning yields meat containing approximately $0.5 \%$ calcium. The bioavailability of the calcium in mechanically deboned meat (MDM) was compared with that from calcium carbonate fed in hand deboned meat (HDM) diets. Processing calcium carbonate with hand deboned meat to bologna, Thuringer or canned meat improved calcium bioavailability but did not increase the bioavailability of the calcium from MDM. Absoption of calcium were $62.7,60.4$ and $60.6 \%$, respectively, from raw MDM, MDM bologna, MDM Thuringer and canned MDM. However, the percentage of calcium absorbed from calcium carbonate was increased slightly from 65.3, 65.9 and 65.6 , respectively, when it was processed as raw HDM, HDM bologna and Thuringer to $69.0 \%$ when processed as canned HDM. The bioavailability of the calcium in MDM was similar to that of calcium carbonate, whether expressed as apparent absorption or as relative biological value.

Consumers are concerned about bone particles when the average size exceeds $0.50 \mathrm{~mm}$ (36). This is probably smaller than the typical particles found in ground red meat products such as sausages and hamburgers. With mechanically deboned poultry meat, however, the size of the bone particles approaches the size of salt grain. No significant difference was found in the number of bone particles retained by the $0.35 \mathrm{~mm}$ screen and the $0.50 \mathrm{~mm}$ screen. In order to pass through the $0.50 \mathrm{~mm}$ screen, the particles must be aligned perpendicularly, and would appear in the product as longer fragments. Again, as yields increased, so did the number of bone particles, which is in part related to the speed at which material passed through the particular deboning machine. Cholesterol levels were higher in skin- less necks than in any other source - which was an unexpected result and certainly of concern for processors wishing to produce low -cholesterol products. Finally, the number of large bone fragments from $0.50 \mathrm{~mm}$ to 0.85 $\mathrm{mm}$ was generally similar for products derived from all hand deboned carcass residues and from each of the deboners. However, the product from skinless necks contained a greater number of smaller bone particles than did other types of mechanically deboned poultry meat. Broiler MDPM(mechanical deboned poultry meat) prepared from backs and necks had significantly higher levels of ash, calcium and iron than fowl MDPM prepared from frames. These differences may be due to the differences in parts deboned and in the age of the birds. For example, softer bones from broilers ( $7-8$ weeks old) resulted in more bone particles being incorporated into MDPM than from the well calcified bones of fowl (39).

\section{MICROBIOLOGICAL QUALITY}

Meat quality can be judged very well by the quantity of microbes. Generally it can be said that if the number of bacteria on the surface of meat exceeds $1 \times 10^{8} \mathrm{cfu} / \mathrm{cm}^{2}$, and inside $0.5 \times 10^{8}-1 \times 10^{8} \mathrm{cfu} / \mathrm{g}$, the meat is unfit for human consumption. If the microbe count is $1 \times 10^{7} \mathrm{cfu} / \mathrm{g}$, the meat is of poor quality.

The surface and inside of meat kept in cold storage contain mainly gram-negative bacteria belonging to the genera: Pseudomonas, Alcaligenes, Achromobacter, Flavobacterium and Serratia and gram-positive Micrococcus. Red meat can also be a source of Salmonella, Clostridium perfrigens, Staphylococcus aureus, Campylobacter spp, Yersinia enterocolitica, Listeria monocytogenes and Aeromonas hydrophila $(40,41)$.

Depending on the hygiene after slaughtering, the surface layers of pork carcasses contain about $10^{2}-10^{4} \mathrm{cfu} / \mathrm{cm}^{2}$. This bacterial population consists mainly of Pseudomonas and Lactobacillus spp. 


\section{Factors influencing microbiological quality}

If the $\mathrm{pH}$ of fresh meat exceeds 6, its shelf life decreases. At pH 6.5 or higher, the meat is of questionable quality. Mechanical deboning, however, can increase the $\mathrm{pH}$ to 6.6 because of release of bone marrow during separation. Thus, $\mathrm{pH}$ alone can not be taken to indicate microbiological deterioration of mechanically deboned meat, even though high $\mathrm{pH}$ improves the growth conditions for microbes. This also limits the shelf life of mechanically deboned meat, which means that it should be used or frozen as quicly as possible after deboning.

According to Field (37) the $\mathrm{pH}$ of hand boned beef is 5.9, whereas that of beef deboned in an auger-type machine is 6.3. The $\mathrm{pH}$ of beef muscle increased from 5.62 to 6.20 when $50 \%$ beef muscle and $50 \%$ marrow with a pH of 6.83 were mixed together. The $\mathrm{pH}$ of lamb muscle increased from $\mathrm{pH} 5.90$ to 6.48 when mixed 50:50 with marrow of $\mathrm{pH} 7.29$ (42). In addition to microbial spoilage, increased $\mathrm{pH}$ also influences the water holding capacity of meat as a result of calcium and magnesium derived from bone. The microbiological quality of mechanically deboned meat is mainly governed by the quality of the bones used, the separation method chosen, hygiene in general and the effectiveness of the refrigeration of the bones and separated meat. During mechanical deboning the temperature should increase as little as possible (43).

According to Abdel-Rahman (44), mechanical deboning does not increase the microbial count of meat in comparison with minced or hand boned meat. It is essential that the mechanical cleaning is performed as fast as possible with well cleaned and disinfected separators.

Kolozyn-Krajewska (45) examined the microbiological problems of hand boned and machine (Seffelaar-Looyen) boned pork. The storage temperature was $+2 \ldots .+4^{\circ} \mathrm{C}$ and the freezer temperature $-18^{\circ} \mathrm{C}$. The results indicated a steady increase in microbial count during cold storage, and also that the microbial population of mechanically deboned meat is greater than that of hand boned meat. The pH-value of mechanically deboned meat was higher than that of hand boned meat. Freezer storage at $-18^{\circ} \mathrm{C}$ decreased the content of aerobic bacteria during 56 days of storage from $3.1 \times 10^{6} \mathrm{cfu} / \mathrm{g}$ to $1.6 \times 10^{5} \mathrm{cfu} / \mathrm{g}$.

Bijker et al. (46) showed that Bacterial Quality Assurance (BQA) in meat production lines must be carried out by a longitudinally integrated safety assurance system based on: (i) selection of raw materials; (ii) avoidance of colonization and proliferation during processing; (iii) maintenance of the original good quality of the product by distribution and storage techniques that avoid contamination and arrest microbial growth.

\section{Pigments}

\section{Characteristics of meat pigments}

The colour of muscle tissue is red. The intensity of colour depends on the quantity of myoglobin. Myoglobin ensures that the muscle can obtain the oxygen necessary for proper functioning. The more an animal uses a muscle, the more myoglobin is present, which is

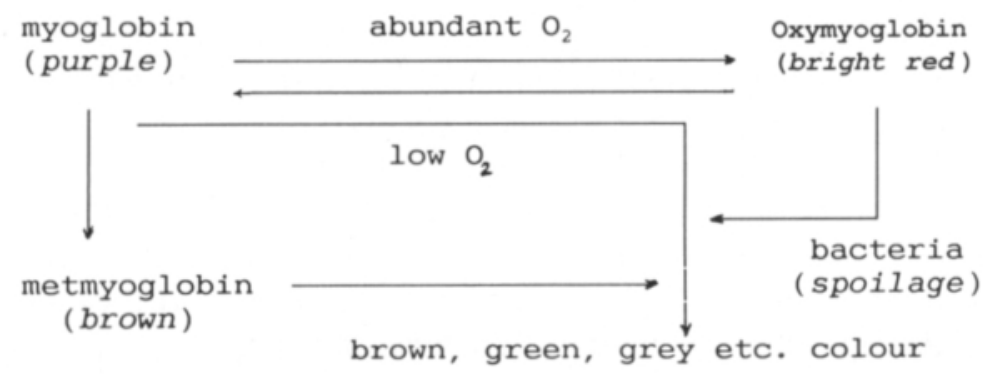

Fig. 2. The effect of oxygen and bacteria on the colour of meat. 
why leg muscles are darker in colour than back muscles. For the same reason, there are colour variations in the meat of different species. The myoglobin content of pork is only one quarter of that of beef. The pigment of meat is not very stable. When it changes into other substances, the change in colour is easily detected. The most important factors governing pigments are temperature, oxygen and bacterial activity (Figure 2) (47).

In retail selling of meat it is very important for the colour to appear natural. In retail packaging, for this reason, a suitably oxygenpenetrating film is used in order to obtain the bright red colour of oxymyoglobin on the surface of the meat. When cut meat is packaged to age in vacuum packs, its surface soon turns darker. The oxygen quantity is so small in vacuum packs that oxymyoglobin formed on the surface of the meat changes back into myoglobin. When the vacuum pack is opened, the colour of the meat changes back to red (48).

\section{Colour of mechanically deboned meat}

Goldstrand (3) showed that mechanically deboned meat (both pork and beef) has a higher colour intensity than corresponding beef and pork meats having the same protein and lipid contents. It has also been shown that blood cells from bone marrow impart a darker colour to mechanically deboned meat (9). The content of red bone marrow in mechanically deboned meat may vary considerably. The changes are mainly caused by the origin of bone, age of the animal, percentage of meat obtained from bones, and the machine used. For instance the quantity of bone marrow in mechanically deboned meat has been analysed by porfyrin quantity (51) and by total pigment quantity (20). One investigator (20) compared total pigment quantities in meat recovered from bones of various origins. A Beehive machine with perforation size $0.44 \mathrm{~mm}$ was used as a mechanical separator. The percentage of the marrow could be calculated by adding four times the calcium percentage to the total meat percentage and dividing the sum by 100 . It was also shown that the largest quantity of meat is obtained from neck bones of young bulls $(45-48 \%)$.

Dawson et al. (51) studied the extraction of lipid and pigment components from mechanically deboned chicken meat. Meat with an elevated $\mathrm{pH}$ resulted in a purplish-red colour and a darker appearance due to alteration of the absorption characteristics of myoglobin. Since meat pigments become more red and darker at higher $\mathrm{pH}$ values, the increased lightness of mechanically deboned chicken meat subjected to the relatively mild bicarbonate washing treatment is probably attributable to extraction of the pigments from the meat rather than alteration or destruction of the pigments.

\section{PACKAGING}

\section{General}

The effect of packaging material on the storage properties of mechanically deboned meat has not been extensively studied. On the other hand, packaging of fresh meat has been widely investigated. For example, it has been shown that microbiological spoilage is at its lowest when the meat is packed into an environment containing carbon dioxide. The second best alternative is vacuum packing, followed by packing under nitrogen gas. The worst alternative is unpackaged meat $(52,53)$.

\section{Vacuum packaging}

Vacuum packaging of meat has become more popular during the past 15 years in many countries.Vacuum packaging causes a shift in the microflora from a predominance of aerobic spoilage species to lactic acid bacteria. As a result of the impermeability of the packaging film, carbon dioxide builds up in the vacuum package (55). This change in atmosphere within the vacuum package causes a decrease in the percentage of aerobic spoilage organisms, 
such as pseudomonas, and an increase in the percentage of lactic acid bacteria. Not only are lactic acid bacteria inhibited less than aerobic spoilage species by the increase in carbon dioxide, but some lactic acid bacteria may actually be stimulated by increased carbon dioxide concentrations (55). Owing to the microbial activity, a slightly $\mathrm{CO}_{2}$-enriched atmosphere is achieved, which in part improves the storage properties of vacuum-packed meat.

\section{Changed atmosphere}

The carbon dioxide content $(15-25 \%)$ of the vacuum pack is most destructive especially to aerobic gram-negative bacteria, such as Pseudomonas spp.

Aavikko (56) reported a study made using mixtures of carbon dioxide (10, 20 and 40\%), oxygen $(0,1$ and $3 \%)$ and hydrogen $(90,79$ and $57 \%$ ) as microbial growth retarders. The effect of carbon dioxide on bacterial growth was significant, and oxygen stimulated the growth of microbes. The oxygen content in a vacuum pack must be minimized, and the meat must be fresh, for carbon dioxide to be formed in the pack. The gas penetrability of the packing material should be as low as possible, and the material should be very durable and stable.

De Zytter and van Hoof (57) studied the microbiological characteristics of the fluid exuded from beef in vacuum pack, and its role in the decay of meat. The results showed that the fluid is microbiologically very susceptible to decay even during a short storage period, and it easily facilitates surface decay of meat. The effects of lactic acid bacteria and the penetrability of the packing material on deterioration of vacuum packed beef have also been studied. Vacuum packed beef was shown to deteriorate at $+5^{\circ} \mathrm{C}$, even without noticeable microbe contamination. The meat spoiled, even though it was vacuum-packed in film with poor oxygen-penetrating qualities (1 $\left.\mathrm{cm}^{3} \mathrm{O}_{2} / \mathrm{m}^{2} / 24 \mathrm{~h} / \mathrm{atm}\right)$. The decay rate increased with the penetrability of the packing material $(58,59)$. Studies on the effects of packing methods and light on the quality and storage properties of retail packaged pork showed that a vacuum pack is better for quality of pork than packing only in PVC film. A shelf life as long as three weeks can be achieved with a vacuum pack, if the storage temperature is $+1 \ldots+3^{\circ} \mathrm{C}(60,61,62)$.

H. Wagner (63) reported that spices and mechanically deboned meat are the ingredients used in the processing of meat which are associated with an increase in the concentration of radiostrontium in the product. Strontium nuclides are enriched primarily in plants, and in the bones of animals with a low transfer rate into the musculature. Secondary contamination by radiostrontium is clearly evident as a result of processing spices and mechanically deboned meat. Secondary contamination with radiocaesium due to additives is of little importance because of the usually small quantities added and the relatively high rate of transfer of caesium from feed into meat.

\section{CONCLUSION}

It has been clearly shown that mechanically deboned meat is quite similar to handboned meat except for the small quantities of bone powder and the variable amounts of red bone marrow that are incorporated into the product during the mechanical deboning process. With continually increasing demands on the world's food supply, new techniques, improvements to old methods, the recovery and utilisation of waste and the introduction of novel foods are all becoming increasingly important. When bones are to be used for mechanical deboning they must be treated, from the outset, in the same way as meat.

In the early 1980's a number of social and scientific concerns have slowed progress in the adoption of deboned meat. Since then, the emphasis has been mainly on conserving protein. The use of bones with deviations of sensory quality resulted generally in MDM of inferior bacteriological quality. Conditions of 
collection and storage of MDM should be futher improved, and stringent uninterrupted refrigeration applied. Factors of concern include the storage stability of products containing MDM, bone particles, increased calcium and phosphate contents, the acceptability of products containing MDM and the protein efficiency ratio and iron bioavailability.
Nevertheless, mechanically deboned meat is a wholesome, nutritious, highly palatable product with a bright future as food.

Lipid oxidation, bacterial contamination, heme pigment release and bone marrow content of the product are major factors which influence the storage properties of all mechanically deboned meats.

\section{References}

1. Kastner, C.L. and Kropf, D.H., Dairy and Food Sanitation, 6, 186 (1986)

2. Von Winter, F.F., Die Fleischerei, 29, 9 (1978)

3. Goldstrand, R.E., Proc. 28th Ann. 1975 Reciprocal Meat Conf., Chicago, 116, (1975)

4. Field, R.A., Kruggel, W.G. and Riley, M.L., J.Anim.Sci., 43, 755 (1976)

5. Newman, P.B., Meat Sci., 5, 171 (1980)

6. Bullock, J.B., WARD, C.E. and McNiel, D.N., American Journal of Agricultural Economics, 63, 738 (1981)

7. Field, R.A., Riley, M.L. and Corbridge, M.H., J.Food Sci. 39, 285 (1974)

8. Field, R.A., Food Technol., 30, 38 (1976)

9. Field, R.A., Kruggel, W.G. and Riley, M.L., J.Anim.Sci., 43, 755 (1976)

10. Field, R.A. and Arasu, P., J.Food Sci. 46, 1622 (1981)

11. Djusic, I. and Djordjevic, V., Proc. Eur. Meat. Res. Work., 25th 859 (1979)

12. Field, R.A., Sanchez, L.R., Kunsman, J.E. and Kruggel, W.G., J.Food Sci. 45, 1109 (1980)

13. Prost, E., Meat, Poultry and Game. Medycyna , Weterynaryjna; 40,(11) 666; 0017 Ref; (1984)

14. Chant, J.L., Day, L., Field, R.A., Kruggel, W.G. and Chang, Y., J.Food Sci., 42, 306 (1977)

15. Essary, E.O. and Ritchey, S.J., Poult.Sci., 47,1953 (1968)

16. Chang, Y.O. and Field, R.A., Nutrition, 107, 1053 (1977)

17. Field, R.A., Proc. 34th Ann.Reciprocal Meat Conf., Chicago, III 143, (1982)

18. Froning, G.W., Arnold, R.G. and Mandigo, R.W., J. Food Sci., 36, 974 (1971)

19. Igene, J.O., King, J.A., Pearson, A.M., and Gray, J.J., J.Agric.Food Chem., 27,838 (1979)

20. Sato, K. and Hegarty, G.R., J.Food Sci., 36, 1098 (1971)

21. Liv, H., J.Food Sci., 35, 590 (1970)

22. LiU, H. and WATtS, M., J.Food Sci., 35, 596 (1970)

23. Barbut, S., Draper, H.H. and Hadley, M., J. Food Prot., 52, 55 (1989)

24. Verma, M.M., Ledward, D.A. and Lawrie, R.A., Meat Sci., 11, 171 (1984)

25. Sмітн, D.M., J.Food Sci., 52, 22 (1987)

26. Tichivangana, J.Z. and Morrissey, P.A., Meat Sci., 15, 107 (1985)

27. Moerck, K.E. and Ball, H.R. Jr., J.Food Sci., 39, $876(1974)$

28. Yasosky, J.J., Aberle, E.D., Peng, I.C., Mills, E.W. and Judge, M.D., J.Food Sci., 49, 1510 (1984)

29. Young, L.L., Searcy, G.K., Blankenship, L.C. Salinsky, J., Hamm, D., Wilson, R. and Willis, B.W., J.Food Sci., 52, 530 (1987)

30. Kunsman, J.E. and Field, R.A., J.Food Sci., 41, 1439 (1976)

31. Mello, F.C., Field, R.A. and Riley, M.L., J.Food Sci., 43, 677 (1978)

32. Kunsman, J.E. and Field, R.A., J.Food Sci., 43, 1375 (1978)

33. Field, R.A. Olson-Womack, S.L. and Kruggel, W.G., J.Food Sci., 42, 1406 (1977)

34. Grunden, L.P. and MacNeIL, J.H., J.Food Sci., 38, 712 (1973)

35. Bijker, P.G.H., Gerats, G.E., Van Logtestiun, J.G., Koolmees, P.A. and Fransen, T., Proc. Eur. Meet, Meat Res. Work., 25th, Budapest, 845 (1979)

36. Schuler, G., The National Provisionen, 5, 15 (1985)

37. Field, R.A., Arasu, P., J.Food Sci. 46, 1622 (1981)

38. Tso, T.N., Mc Laughlin, K., Mahoney, A.W. and Hendricks, D.G., Journal of Nutrition, 114, 946 (1984)

39. Barbut, S. Draper, H.H. and Cole, P.D., J. Food Prot., 52 , 21 (1989)

40. Roberts, T.A., Proc. 33th International Congress of Meat Science and Technology, 43 (1987)

41. Kärkiñinen, T., The Finnish Engineers' Post Graduate Institute 178-87 (Finnish) (1987)

42. Arasu, P., Field, R.A., Kruggel, W. and Miller, G.J., J.Food Sci., 46, 1114 (1981)

43. Ostovar, K., Mac Neil, J.H. and O'donnell, K., J.Food Sci., 36, 1005 (1971) 
44. Rahman, Hasny Abdel., Fleischwirtsch., 67, 191 (1987)

45. Kolozyn-Krajewska, D.M., Meat Production and Processing, 56 (1987)

46. BiJker, P.G.H., van Logtestiun, J.G. and Mossel, D.A.A., Meat Sci., 20, 237 (1987)

47. RYYnÃnen, T., The book of meat products II, (Finnish) Helsinki, 733 (1982)

48. Price, J.F. and Schweigert, B.S., The Science of Meat and Meat Products, Protective packaging of meat and meat products, Westport 489 (1987)

49. Walters, C.L., Proc. 21st Easter School in Agricultural Science Univercity of Nottingham 385 (1975)

50. Miller, G.J., Krujggel, W.G. and Field, R.A., J.Food Sci., 43, 636 (1978)

51. Dawson, P.L. Sheldon, B.W. and Ball, H.R. Jr., J.Food Sci., 53, 1615 (1988)

52. Ahvenainen, R., Food Rev Intern., 4, 45 (1988)

53. Eyles, M.J. and Adams, R.F., Int.J.Food Microbiol., 3, 321 (1986)

\section{SELOSTUS}

\section{Mekaanisesti luista erotettu liha}

\section{Riihonen,* J. Laine* ja P. Linko**}

* Lihateollisuuden tutkimuskeskus PL 56, SF-13101 Hämeenlinna, Suomi

** Biotekniikan ja elintarviketeknologian laboratorio Kemian tekniikan laitos

Teknillinen korkeakoulu, SF-02150 Espoo, Suomi

Mekaanisesti luista erotettu liha, MDM (mechanically deboned meat) MDT (mechanically deboned tissue), on yhă enenevăssă määrin lisăäntynyt lihateollisuudessa. Näin saadun lihamassan ominaisuudet, korkea valkuaisainesisältoo, hyvăt teknologiset ominaisuudet ja suhteellisen alhainen hinta tekevăt tuotteesta hyödyllisen ja käyttökelpoisen raaka-aineen. Useiden maiden lainsảảdännőssă on annettu tällaisen lihan laatuun, käyttoooon ja säily-
54. Gıl., C.O. and Newton, K.G., Meat Sci.,2, 207 (1978)

55. Newsome, R.G., Seman, D.L., Langlois, B.E., Woody, W.G., Fox, J.D. and GAY, N., J.Food Sci., 52, 861 (1987)

56. Aaviкко, J., The publication of Finnish Meat Research Centre 291-1 (Finnish) 27-28 (1983)

57. De Zutter, L. and van Hoof, J., Proc. Eur. Meet, Meat Res. Work., 28th, Madrid, 355 (1982)

58. Egan, A.S. and ShaY, B.J., J.Food Sci., 47, 1119 (1982)

59. Tăndler, K., Die Fleischerei 33, 772 (1982)

60. TÁndler, K., Die Fleischerei 34, 37 (1983)

61. Ahvenainen, R., Gas packaging of chilled meat products and ready-to-eat foods, Technical Research Centre of Finland, 58, 34 (1989)

62. Rozenberg, T.V. and Pereira, A.S., Revista Ceres, 45, 45 (1988)

63. WAGNer, H., Fleischwirtsch., 68, 656 (1988)

Deb Ms received June 111990

tykseen liittyviä ohjeita. Vaikkakin helposti tapahtuvat rasvan hapettuminen, mikrobiologinen kontaminoituminen, hemipigmenttien vapautuminen ja luuytimen erottuminen tuotteeseen rajoittavat tuotteen säilyvyyttä on mekaanisesti luista erotettu liha kăyttökelpoista, ravintoarvoltaan hyvăä prosessoitujen lihavalmisteiden kăyttőon soveltuvaa raaka-ainetta. 